DOI: $10.4274 /$ tpa.46.75

\title{
Bir yenidoğan yoğun bakım biriminde adenovirus salgın yönetimi
}

\section{The management of an adenovirus epidemic in a neonatal intensive care unit}

\author{
Betül Siyah Bilgin, Mehmet Yalaz, Özge Altun Köroğlu, Mete Akisu, Candan Çiçek*, Çağrı Büke**, Nilgün Kültürsay \\ Ege Üniversitesi Tıp Fakültesi, Çocuk Sağlığı ve Hastalıkları Anabilim Dalı, Yenidoğan Bilim Dalı, lzmir, Türkive \\ ^Ege Üniversitesi Tıp Fakültesi, Mikrobiyoloji ve Klinik Mikrobiyoloji Anabilim Dalı, Izmir, Türkiye \\ ** Ege Üniversitesi Tıp Fakültesi, Enfeksiyon Hastalıkları Anabilim Dalı Enfeksiyon Kontrol Komitesi, Izmir, Türkiye
}

\begin{abstract}
Özet
Amaç: Adenovirüs ile gelişen epidemik konjunktivit genellikle göz doktorlarının muayenesi sırasında doğrudan temasla bulaşır. Bu yazı yenidoğan yoğun bakım biriminde (YYBB) adenovirus salgın yönetimi deneyimimizi paylaşmak amacıyla yazılmıştır.

Gereç ve Yöntem: 14.09.2009-17.10.2009 tarihleri arasında YYBB'de görülen adenovirus salgını geriye dönük incelenmiştir. Bu dökümde tıbbi kayıtlar ve Enfeksiyon Kontrol Kurulu'nun kayıtlarının verileri kullanılmıştır. Serviste yatmakta olan 15 hastadan (9 kız, 6 erkek) ve 25 çalışandan konjunktiva, nazofarenks, dışkı sürüntü örnekleri toplandı. Salgın süresince tüm bebeklerden haftalık örnekler alındı. Örneklerin tümüne eş zamanlı olarak direkt floresan antikor testi ve "shell vial" hücre kültürü yöntemi uygulandı. Adenovirüs konjunktivit tanısı klinik bulgular ve/veya direkt floresan antikor ve hücre kültürlerinde üretilerek konuldu. Analizler yapııırken SPSS 13,0 istatistik programı kullanıldı.

Bulgular: Prematüre retinopati taraması amacı ile yapılan göz bakısı ertesinde o gün muayene edilen beş bebekte, muayene eden hekimde ve muayene edilmeyen iki bebekte konjunktivit gelişti. Salgın sırasında YYBB'de yatmakta olan 15 bebekten 10'unda konjunktivit, bu olguların beşinde ishal ve konjunktivit beraber görüldü. Beş hemşirede klinik konjunktivit saptandı ve bir hemşirede adenovirus direkt floresan antikor testi ile gösterildi, hücre kültüründe üretildi. Konjunktiviti olan tüm hemşirelerin çalışmalarına ara verildi. Bulgusu olan üç bebeğin göz sürüntüsünde ve bir bebeğin de transtrakeal sıvısında adenovirus antijeni saptandı. Hücre kültürü ile tanı doğrulandı. Enfeksiyon kontrol kurul önerileri ile standart önlemlere ek olarak temas ve damlacık izolasyon önlemleri alındı.

Çıkarımlar: Enfeksiyon kontrol önlemlerinin titizlikle uygulanması, birime hasta girişinin durdurulması, birimin ayrıntılı temizlenmesi ve dezenfeksiyonu salgının yayılmasını ve süresinin uzamasını engellemiştir. İkinci bir salgın dalgası olmamış ve hiç hasta kaybedilmemiştir. (Türk Ped Arş 2011; 46: 202-6)

Anahtar sözcükler: Adenovirus, salgın, yenidoğan, yönetim

\section{Summary}

Aim: Epidemic conjunctivitis caused by adenovirus frequently spreads by management contact during ophtalmologic examination. This report is written to share our experience on an adenovirus epidemic in our neonatal intensive care unit .

Material and Method: The detailed medical and infection control committee records of the newborns and personnel together cared in Ege University neonatal intensive care unit in the period between 09.14.2009-10.17.2009 are used in this report. Conjunctival, nasopharyngeal and stool samples were collected from 15 patients, who were living in service ( 9 girls, 6 boys), and from 25 personnel. Weekly samples were collected from infants during the epidemic. Management fluorescence antibody test and "shell vial" cell culture method were conducted synchronously to all samples. Adenovirus conjunctivitis was diagnosed according to clinical evidence and/or detection of adenovirus in management fluorescence antibody test and cell cultures. During analysis, SPSS 13,0 statistics programme was used.

Results: Severe conjunctivitis occurred within three days of fundus examination for screening of retinopathy of prematurity in five newborns who were examined in the same day and in the ophtalmologist who had examined the infants and in two newborns who were not examined. Ten of 15 infants who were cared at the neonatal intensive care unit during this epidemic had conjunctivitis, five of whom had also gastroenteritis. Five nurses had conjunctivitis and had a leave for therapy and isolation. In one of them AV was detected with direct fluorescence antibody test and also in cell cultures. Adenovirus antigen was detected in three conjunctival swabs and one tracheal aspirate of symptomatic infants. The diagnosis was confirmed with tissue cultures. In addition to standard precautions droplet precautions were also taken with the recommendation of the Infection Control Committee. Conclusions: The meticulous infection control measures, closing the unit to new admissions, detailed cleaning and decontamination of neonatal intensive care unit prevented the epidemic to spread further and limited the duration of the epidemic. No further second epidemics occurred and all patients recovered. (Turk Arch Ped 2011; 46: 202-6)
\end{abstract}

Key words: Adenovirus, epidemic, management, newborn

Yazışma Adresi/Address for Correspondence: Dr. Betül Siyah Bilgin, Ege Üniversitesi Tıp Fakültesi, Çocuk Sağlığı ve Hastalıkları Anabilim Dalı Yenidoğan Bilim Dalı, İzmir Türkiye E-posta: betulsiyah@yahoo.com Geliş Tarihi/Received: 04.09.2010 Kabul Tarihi/Accepted: 14.04.2011 


\section{Giriş}

Adenovirüs (AV) çift sarmallı zarfsı DNA virüsüdür ve yedi alt cins (A'dan G'ye kadar) altında toplanan 52 farklı serotip ile insanlarda enfeksiyonlara yol açabilmektedir $(1,2)$. Bebeklerde akut solunum yolu hastalıklarının \%5-11'inin nedeni AV'dir. Ayrıca faringokonjunktival ateş, foliküler konjunktivit, epidemik keratokonjunktivit, miyokardit, hemorajik sistit, akut diyare, invajinasyon ve ansefalomiyelite de neden olmaktadır. Foliküler konjunktivit ve keretokonjunktivitin de en sık nedenidir. Özellikle AV tip 4, 8, 19 ve 37'nin epidemik keratokonjunktivit ile ilişkili olduğu gösterilmiştir (3).

Adenovirüs enfeksiyonları immün yetersizliği olanlarda, T veya $B$ hücresi işlev bozukluğunda ve hipogamaglobülinemisi olan olgularda sık görülmektedir. Yenidoğanlarda T lenfositler ve doğal öldürücü hücrelerin sitotoksik aktiviteleri azalmıştır. Ayrıca yenidoğanlarda B lenfositler de sınırlı antikor oluşturur ve erken doğmuş bebeklerde anneden geçen antikor miktarı da yetersizdir. Bu nedenlerle yenidoğanlar AV enfeksiyonlarına karşı çok duyarlıdır $(1,4)$.

Adenovirüs doğrudan temas, aerosoller ve eşyalar ile bulaşır. Dış ortama oldukça dayanıkıdır. Epidemik keratokonjunktivitin genellikle göz doktorlarının muayenesi sonrasında meydana geldiği gösterilmiştir (2).

Bu makalede bir yenidoğan yoğun bakım biriminde (YYBB) AV enfeksiyonu salgın yönetimi anlatılmaktadır.

\section{Gereç ve Yöntem}

14.09.2009 - 17.10.2009 tarihleri arasında YYBB'de görülen AV salgını geriye dönük incelenmiştir. Bu dökümde tıbbi kayıtlar ve enfeksiyon kontrol kurulunun kayıtlarının verileri kullanılmıştır. Salgın sırasında konjonktivitli bebeklerden göz alt kapağı sürüntüsü, ishal varsa dışkı örneği, bulgusu olmayan bebeklerden nazofarenks sürüntüsü alındı. Bulgusu olan çalışandan konjunktivit varsa göz alt kapağı sürüntüsü, üst solunum yolu enfeksiyonu varsa boğaz sürüntüsü alındı. Bulgusu olmayan çalışandan da boğaz sürüntüsü alındı. On beş hastadan (9 kız, 6 erkek) ve 25 doktor, hemşire ve çalışandan sürüntü örnekleri toplandı ve viral transport besiyeri (Universal transport medium (UTM) kit, Copan Diagnostics, Brescia, Italy) içinde soğuk zincir kurallarına uyularak hemen laboratuvara gönderildi. Örneklerin tümüne eş zamanlı olarak direkt floresan antikor (DFA) testi (duyarlılık \%86, özgüllük \%100) ve "shell vial" hücre kültürü yöntemi uygulandı. Adenovirüs konjunktivit tanısı klinik bulgular ve/veya DFA ve hücre kültürlerinde üretilerek konuldu (5). Salgın süresince tüm bebeklerden örnekler haftalık olarak alındı. Haftalık örnek alımı tüm bebeklerin konjunktivit bulguları kayboluncaya kadar ve serolojik testler ve kültür sonuçları negatif gelinceye kadar sürdürüldü (33 gün). Değerler ortalama \pm standart sapma olarak verildi. Gruplar arasında oran karşılaştıııırken Fisher testi, ortalamalar karşılaştırılırken Mann Whitney $U$ testi kullanıldı. P değeri $<0,05$ olduğunda istatistiksel olarak anlamlı kabul edildi. Analizler yapılırken SPSS 13,0 istatistik programı kullanıldı.

\section{Bulgular}

Salgın sırasında YYBB'de yatmakta olan 15 bebekten 10'unda konjunktivit, beşinde eşzamanlı ishal ve konjunktivit görüldü. Konjunktivit gelişen bebeklerden beşine üç gün önce prematüre retinopatisi kontrolu için göz bakısı yapıımıştı.

Konjunktivit gelişen 10 bebeğin doğum ağırlıkları ortalama $1090 \mathrm{~g} \mathrm{(600-1990} \mathrm{g),} \mathrm{gestasyonel} \mathrm{yaşları} \mathrm{26-33} \mathrm{hafta} \mathrm{arasın-}$ da (ortalama $28,5 \pm 2$ hafta), salgın başlangıcında yaşları 3-104 gün arasında (ortalama $60 \pm 37$ gün) değişmektedir. Konjunktivit gelişen olgulardan üç bebek erkek ve yedi bebek kızdı. Konjunktivit gelişen 10 bebeğin üçünde göz sürüntüsünde ve birinde transtrakeal aspiratında olmak üzere AV DFA ve hücre kültüründe üretilerek gösterildi.

Bulgusu olan ve olmayan bebekler doğum ağırlıkları, cinsiyet, ventilatörde izlem, göz bakısı, göz bakısı sayısı, salgın sırasındaki yaşları, bronkopulmoner displazi (BPD) tanısı ve kostikosteroid tedavisi açısından karşılaştıııımıştır. Bulgusu olan bebeklerde, salgın sırasındaki yaş, salgının hemen öncesinde göz bakısı varlığı, göz bakısı sayısı, salgın öncesinde kortikosteroid kullanımı ve BPD bulgusu olmayan bebeklerle karşılaştııılığında istatistiksel anlamlı olarak fazla bulunmuştur. İki grubun doğum ağırlığı, cinsiyet ve ventilatör bakımı varlığı istatistiksel olarak farklı bulunmamıştır (Tablo 1). Konjunktivit gelişip laboratuvar incelemelerinde AV gösterilemeyen ve gösterilen iki grup bebek doğum ağılıkları, cinsiyet, ventilatörde izlem, göz bakısı, göz bakısı sayısı, salgın sırasındaki yaşları, BPD tanısı ve salgın öncesinde kostikosteroid tedavisi açısından karşılaş̧ıııımış ve istatistiksel olarak anlamlı

Tablo 1. Salgın sırasında bulgusu olan (konjunktivit-ishal) 10 bebeğin ve bulgusu olmayan beş bebeğin özelliklerinin karşılaştırılması

\begin{tabular}{|l|c|c|c|}
\hline Özellikler & Bulgulu & Bulgusuz & p \\
\hline Doğum ağılı̆ı̆ (gr) & $1090( \pm 426)$ & $1248( \pm 355)$ & 0,32 \\
\hline Cinsiyet (erkek) & $3(\% 30)$ & $3(\% 60)$ & 0,32 \\
\hline Gestasyonel yaş (hafta) & $28,3( \pm 2,3)$ & $29( \pm 1,8)$ & 0,53 \\
\hline Enfeksiyon anında ventilatör tedavisi & $7(\% 70)$ & $2(\% 40)$ & 0,32 \\
\hline Enfeksiyon anında yaş (gün) & $58,2( \pm 37)$ & $11( \pm 11)$ & 0,014 \\
\hline Göz bakısı sayısı & $2,8( \pm 2,4)$ & 0 & 0,020 \\
\hline Bronkopulmoner displazi (\%) & $8(\% 80)$ & 0 & 0,007 \\
\hline Kortikosteroid kullanımı (\%) & $8(\% 80)$ & 0 & 0,007 \\
\hline Göz bakısı & $7(\% 70)$ & 0 & 0,026 \\
\hline
\end{tabular}


fark bulunmamıştır (Tablo 2). Salgın başladığında kostikosteroid tedavisi alan olgu yoktu.

Konjunktivit tedavisi için bulgusu olan olgulara streoid dışı antienflamatuar göz damlaları ve antibiyotikli göz damlaları kullanıldı. Bulgusu olan bebeklerde haftalık kontrol sürüntülerinde AV saptanmadı. Salgın süresince kaybedilen bebek olmadı.

Ayrıca göz hekimi ve beş hemşirede konjunktivit gelişti ve birinde DFA yöntemi ile AV pozitif olarak değerlendirildi. Diğerleri negatif bulundu. Çalışanların taramasında bulgusuz üç kişinin nazofarenks sürüntülerinde AV DFA ile saptandı.

\section{Salgının epidemiyolojisi ve yönetimi}

Salgın sırasında YYBB'de üç odada toplam 15 bebek yatmaktaydı. Bebeklerden beșinde prematüre retinopatisi için yapılan göz bakısından üç gün sonra konjunktivit görüldü. Göz bakısını yapan hekimin de üç gün sonra konjunktivit nedeni ile rapor aldığı öğrenildi.
Salgının üçüncü gününde göz bakısı yapılan beş ve yapılmayan iki olmak üzere toplam yedi bebekte ve beş hemşirede konjunktivit görüldüğünden Enfeksiyon Kontrol Kurulu ile acil toplantı yapıldı ve alınacak önlemler kararlaştııılı. Enfeksiyon Kontrol Kurulu önerileri doğrultusunda bulgusu olan bebeklerden konjunktivit varsa göz sürüntüsü, ishal varsa dışkı örneği gönderildi. Bulgusuz bebeklerden ve çalsşandan sadece nazofarenks sürüntü örnekleri çalışıldı. Ayrıca bulgusu olan çalışandan da konjunktivit varsa göz sürüntüsü, üst solunum yolu enfeksiyonu varsa nazofarenks sürüntüsü gönderildi. Örneklerin tümüne eş zamanlı olarak DFA testi ve "shell vial" hücre kültürü yöntemi uygulandı.

Enfeksiyon Kontrol Kurulu önerileri doğrultusunda AV salgını sırasında bilinen önlemlere ek olarak temas ve damlacık izolasyon önlemleri alındı ve birimin girişine ve servis içinde çeşitli yerlere yazılı olarak bu önerilerle ilgili bilgilendirme tabloları asıldı (Tablo 3). Adenovirüs izolasyonu için küvöz temizliği ve dezenfeksiyonu yazılı olarak belirlendi ve çalışanlara anlatılarak denetimi yapıldı (Tablo 4).

Tablo 2. Konjunktivit olup AV gösterilen dört ve gösterilemeyen altı bebeğin özelliklerinin karşılaştırılması

\begin{tabular}{|l|c|c|c|}
\hline Özellikler & Seroloji (+) & Seroloji (-) & $\mathbf{p}$ \\
\hline Doğum ağırlı̆ı̆ (gr) & $1030( \pm 476)$ & $1130( \pm 433)$ & 0,454 \\
\hline Cinsiyet (erkek) & $1(\% 25)$ & $2(\% 33)$ & 1 \\
\hline Gestasyonel yaş (hafta) & $28,5( \pm 2,4)$ & $28,5( \pm 2,3)$ & 0,91 \\
\hline Enfeksiyon anında ventilatör tedavisi & $4(\% 100)$ & $3(\% 50)$ & 0,20 \\
\hline Enfeksiyon sırasındaki yaş (gün) & $83( \pm 16)$ & $45( \pm 39)$ & 0,20 \\
\hline Göz bakııı sayısı & $3,7( \pm 1)$ & $1,7( \pm 2,4)$ & 0,12 \\
\hline Bronkopulmoner displazi (\%) & $4(\% 100)$ & $4(\% 66)$ & 0,46 \\
\hline Kortikosteroid kullanımı (\%) & $4(\% 100)$ & $4(\% 66)$ & 0,47 \\
\hline Göz bakısı & $4(\% 100)$ & $3(\% 50)$ & 0,20 \\
\hline
\end{tabular}

Tablo 3. Damlacık ve temas izolasyon önlemleri

1. Hastayla temastan önce ve sonra eller mutlaka yıkanmalıdır ve/veya alkol içeren el dezenfektanı ile el hijyeni sağlanmalıdır.

2. Çapraz enfeksiyonu engellemek için hastadan hastaya geçmeden önce eller mutlaka yıkanmalı ve alkol içeren el dezenfektanı ile el hijyeni sağlanmalıdır.

3. Hastayla temas öncesi eldiven, maske koruyucu önlük ve koruyucu gözlük kullanılmalıdır (Resim 1). Koruyucu gözlük kullanıldıktan sonra \%70'lik alkol ile dezenfekte edilmelidir.

4. Hastanın vücut bakımında farkı bölgelere geçilmeden önce eller yıkanıp, eldiven değiștirilmelidir.

5. Birimde yıkanan çamaşıllar en $\mathrm{az} 71^{\circ} \mathrm{C}$ 'de ve 25 dakika yıkanmalı, temiz ve kirli çamaşıllar ayrı yerlerde depolanmalıdır.

6. Çamaşırhaneye gidecek çamaşırlar kırmızı renkli torba içerisinde aktarılmalıdır.

Tablo 4. Adenovirüs izolasyonu için küvöz temizliği ve dezenfeksiyonu

1. Küvözlerin içi ve dışı her gün asit içeren dezenfektanla temizlenmelidir.

2 Temizlik günde iki kere ve ayrıca ek olarak görünür kirlenme olduğu zaman yapılmalıdır.

3. Her küvöz için ayrı temizlik bezi kullanılmalıdır.

4. Küvözlerde temizlik işlemi yukarıdan aşağıya doğru olmalı.

5. En yoğun bulaş bölgesi olan dış kapaklar, bu kapakları saran yastıkçık ve kollar gün içinde en az iki kez dezenfektanla (tercihen \%70'lik alkol) ile silinmelidir.

6. Yatakların yüzeyinde bütünlük bozulması varsa yenisi ile değiştirilmelidir. Hasta yataklarının şiltesinin hasarlanması etkin dezenfeksiyon ve sterilizasyonu önler.

7. Kullanım sonrası ve her bebek değişiminde küvöz ve açık yatakların temizliği ve dezenfeksiyonu yapılmalıdır.

8. Bebek uzun süredir izleniyorsa küvözüne en az haftada bir dezenfeksiyon işlemi uygulanır (1000 $\mathrm{g}$ altında bebekler için beş günde bir). Küvözün önce ayrılabilir bütün parçaları çıkarılmalı, fırçalanarak yıkanmalı ve deterjanla ovularak temizlenmelidir. Küvözün tüm parçalarının 5000 ppm klor cözeltisi ile dezenfeksiyonu yapılmalıdır.

9. Tekrar kullanmadan önce küvözler havalandırımalıdır. Küvözler kullanılmayacak ise, nemlendirici bölümüne su konulmadan, dezenfeksiyon sonrası 24 saat boyunca ısıtılarak tam kuruması sağlanmalıdır.

10. Su konulan kaplar haftada bir veya her bebek değişiminde steril edilmeli, her 24 saatte bir distile veya steril su doldurulmalıdır.

11. Fan varsa temizlenmeli ve dezenfekte edilmelidir. 
Bulgusu olan bebekler aynı odaya alındı ve hemşireleri ayrıldı. Taburcu olabilecek hastalar hızla taburcu edildi. Konjunktiviti olan beş hemşirenin çalışmasına izin verilmedi. Birime hasta alımı durduruldu, servisin genel hijyenik temizliği ve dezenfeksiyonu için olgular geçici olarak oluşturulan bir yoğun bakım servisine taşındı ve tüm servisin havalandırma sistemi gözden geçirildi, temizlik yapıldı ve servisin duvarları yeniden boyandı.

Salgının altıncı gününde bulgusuz bebeklerin bulunduğu odada üç bebekte daha konjunktivit gelişti ve bulgu veren bebeklerin olduğu odaya alındı. Bu bebeklere daha önceden retinopati taraması yapılmamıștı. Temas ve izolasyon önlemleri bulgulu, bulgusuz tüm bebeklere uygulandı. Salgının altıncı gününden sonra yeni konjunktivit olgusuna rastlanmadı. Bebeklerin hepsi 33 gün boyunca haftalık sürüntü örnekleri ile kontrol edildi. Adenovirüs tanı testleri tüm bebeklerde negatifleştiği ve tüm bebeklerdeki konjunktivit bulguları kaybolduğundan salgının 33. gününde geçiçi oluşturulan yoğun bakım servisinden YYBB'ye geçildi. Enfeksiyon kontrol önlemleri son olgu görüldükten 27 gün sonra, salgının 33. gününde sonlandırıldı (Şekil 1).

Virüsün göz bakısı sırasında birime girdiği düşünüldüğünden göz hekimleri ile toplantı yapıldı ve Amerikan Oftalmoloji Akademisi kararları doğrultusunda prematüre retinopatisinin birimde değerlendirilmesi sırasında alınması gereken önlemler kararlaştıııldı (Tablo 5).

Sıfırıncı gün beş bebeğe göz bakısı yapılmıştır. Üçüncü gün beş göz bakısı yapılan ve iki yapılmayan toplam yedi bebekte konjunktivit gelişti. Üçüncü gün temas ve damlacık izolasyon önlemleri alındı, bulgusu olan ve olmayan bebekler ayrı odalara alındı, hemşireleri ayrıldı. Altıncı gün bulgusuz bebeklerin olduğu odada üç bebekte konjunktivit gelişti ve bulgusu olan bebeklerin olduğu odaya alındılar. Servise yeni hasta alınmadı, ziyaretçi kabul edilmedi. Acil sorunu kalmayan bebekler taburcu edildiler, ailelere önlemler hakkında bilgi verildi. Bulgusu olan bebeklerden birisi taburcu olduktan sonra

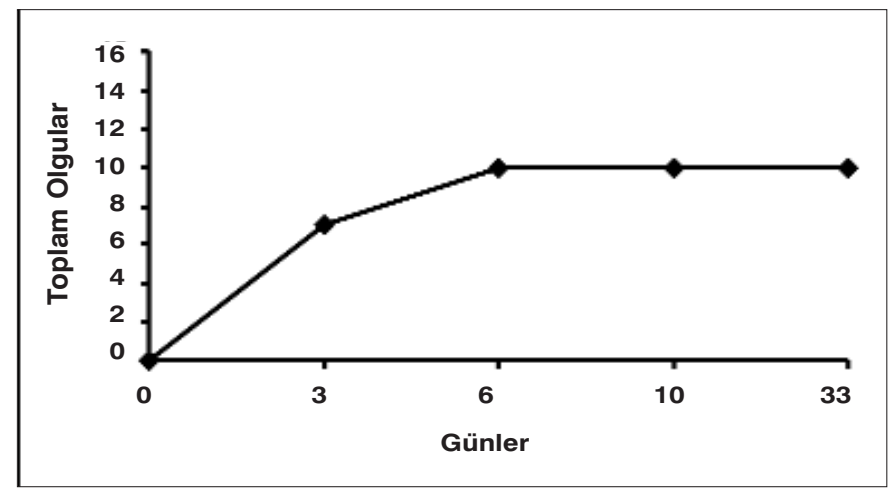

Şekil 1: Salgın gelişimi zaman grafiği babasında konjunktivit gelişti. Onuncu gün geçici oluşturulan yoğun bakım birimine taşınıldı. Tüm servis dezenfekte edildi. Başka olgu saptanmadı, alınan kontrol sürüntü örnekleri negatif bulundu. Salgının 33. gününde YYBB'ye geri taşınıldı. Tüm bebekler bulgusuz olduğundan ayrıca haftalık bakılan DFA ve hücre kültüründe AV gösterilen olgu saptanmadığından temas ve damlacık izolasyon önlemleri sonlandırıldı.

\section{Tartışma}

Adenovirüsler uzun zamandır hastaneden kazanılmış enfeksiyonlarla ilişkilendirilmektedir ve özellikle yoğun bakım birimlerinde çok sayıda salgın bildirilmiştir. Salgınlar sıklıkla YYBB'lerde bildirilmiştir. Salgınların AV tip 8 ile olduğunda ölüm oranının daha düşük, tip 30 ve tip 7 ile olduğunda ölüm oranının pnömoniye bağı solunum yetersizliği nedeni ile daha yüksek olduğu gösterilmiştir $(4,6,7)$. Bu nedenle salgınların şiddetinin virüsün serotipine bağlı olabileceği düşünülmüştür. Birimimizdeki salgında ölen bebek olmamıştır. Adenovirüs tiplendirmesi ülkemizde bu incelemeyi yapabilecek merkez bulunamadığından yapılamamışıtır. Örnekler daha sonra değerlendirmek üzere saklanmıştır. Birimimizdeki salgında bebek kaybedilmemesi, pnömoni görülmemesi ve ülkemizde yapılan bir çalışmada en sık viral kojunktivit etkeni olarak AV tip 8 elde edilmesi nedeniyle etkenin AV tip 8 olabileceği düşünüldü (8).

Bazı çalışmalarda kostikosteroidlerin AV ile enfekte erken doğmuş bebeklerde klinik durumun kötüleşmesine hatta kaybedilmesine neden olabileceği ileri sürülmüştür (7). Salgın döneminde tüm göz bakısı yapılan bebeklerde bulgu konjunktivit olduğundan göz bakısı dışında başka bir risk etmeni saptanmadı. Bulgusu olan ve olmayan bebeklerin salgın öncesinde BPD varlığı ve bu nedenle kortikosteroid kullanımı karşılaştırılığında konjunktiviti olan bebeklerde BPD ve kortikosteroid kullanımı istatistiksel olarak daha fazla anlamlı bulundu. Ancak salgın sırasında kostikosteroid tedavisi alan hasta bulunmamaktaydı. Bu durumun bebeklerin ağır belirtiler geliştirmesini ve kaybını önlediğini düşündük.

Bulgusu olan bebeklerin yaşları retinopati muayenesi doğum sonrası 4-6 hafta civarında ve retina gelişinceye kadar 1-2 hafta aralarla tekrarlanarak yapıldığı için bulgusu olmayan olgulardan istatistiksel olarak daha büyük ve retinopati bakı sayıları da fazladır.

Adenovirüs salgınları sırasında çeşitli tedaviler denenmiş ve farklı sonuçlar bulunmuştur. İntravenöz immünglobulinin (IVIG) antiviral antikorlar içermesi nedeni ile viral enfeksiyonu önleyebileceği düşünülmüş ancak aksine bir çalışmada viral enfeksiyonu önlem amaçlı kullanılan iViG'in AV salgınına neden olduğu gösterilmiştir (9). Ayrıca nadir görülen AV serotiplerine karşı ticari iviG'lerin yeterince antikor içermesi beklenen bir şey değildir. Ribavirin veya son zamanlarda sidovir'in de yararı gösterilmiştir (10). Salgın sırasında olguları-

Tablo 5. Yenidoğan yoğun bakım biriminde göz hekiminin uyması gereken kurallar

1. Birime girişte göz hekimleri önlük, giyecek ve maske takacak.

2. Göz bakısı sırasında eldiven kullanılacak ve bir hastadan diğerine geçerken değiştirilecek.

3. Kullanılan aletler 10 dakika boyunca \%70'lik alkol sıvısında bekletilecek ve alkollü sıvı günde iki defa değiştirilecek.

4. Her hastaya ayrı blefarostat kullanılacak. 
mızda sistemik belirtiler görülmediğinden IViG, ribavirin veya sidovir tedavisi verilmemiştir. Sadece steroid dışı antienflamatuar göz damlaları ve antibiyotikli göz damlaları konjunktivit tedavisi için kullanılmıştır.

Yenidoğan yoğun bakım birimlerinde görülen AV salgınlarının literatürde saptanabildiği kadarı ile üç tanesinde göz muayeneleri sonrasında AV salgını olduğu gösterilmiştir. Çoğunlukla etken adenovirus tip 8 olarak belirtilmiştir $(4,6,7)$.

Adenovirüsün olgularımıza göz incelemeleri sırasında bulaştığı ve onları enfekte ettiği düşünülmüştür. Çünkü göz bakısından üç gün sonra olgularda konjunktivit görüldü ve aynı zamanda göz bakısı yapan hekim de konjunktivit nedeni ile eş zamanlı rapor almış idi. Konjuktiviti olan ve olmayan bebekler karşılaştırıldığında konjunktivi olan bebeklerde göz bakısı sayısı istatistiksel anlamlı olarak daha fazla bulunmuştur. Geriye dönük incelendiğinde bu dönemdeki göz bakıları sırasında maske, eldiven kullanılmadığı ve aletlerin yeterli sayıda olmadığı, dezenfekte edilmediği anlaşıldı. Salgının yayıımasında bu eksikliklerin rolü olduğu düşünüldü.

Adenovirüs plastik ve metal yüzeylerde 49 gün, giysi ve kağıtta ise 10 gün canlıı̆̆ını korumakta ve uzun süre dışkı ile virüs atılmaktadır $(2,11)$. Salgın sırasında ve daha sonra bakılan dışkılarda AV saptanmadı. Salgın başladığında birime hasta alımı AV DFA ve hücre kültüründe negatif saptanıncaya kadar (toplam 33 gün süreyle) durduruldu. Salgının erken fark edilmesi, gerekli izolasyon önlemlerinin alınıp titizlikle uygulanması, birime hasta girişinin durdurulması, birimin taşınarak ayrıntılı temizlenmesi, salgının yayılmasını ve süresinin uzamasını engellemiştir.

Göz doktorlarıyla toplantılar yapılarak birimin içerisinde yapılacak olan göz bakılarının yazııı standartlara uygun şekilde yapılması sağlanmıştır. Alınan tüm önlemler sonucunda ikinci bir salgın dalgası olmamış ve hiç hasta kaybedilmemiştir.
Adenovirüs salgınları YYBB'lerde servis kapatılması ve çok ciddi önlemlerin alınmasını gerektiren durumlardandır ve tekrarlama riski yüksektir. Sürekli eğitim enfeksiyonlardan korunmada en temel öğedir.

\section{Çıkar çatışması: Bildirilmemiştir.}

\section{Kaynaklar}

1. American Academy of Pediatrics. Adenovirus enfeksiyonları. İçinde: Pickering LK, Baker CJ, Long SS, McMillan J, (eds) Redbook: 2006 enfeksiyon hastalıkları komite raporu. 27. baskı. Elk Grove Village: IL American Academy of Pediatrics, 2006: 211-2.

2. Henquell $\mathrm{C}$, Boeuf $\mathrm{B}$, Mirand $\mathrm{A}$, et al. Fatal adenovirus infection in a neonate and transmission to health-care workers. J Clin Virol 2009; 45: 345-8.

3. Behrman RE, Kliegman RM, Jenson HB. Nelson textbook of pediatrics. 18 th ed. Pennsylvania: Saunders, 2007; 259: 1393-4.

4. Faden H, Wynn RJ, Campagna L, Ryan RM. Outbreak of adenovirus type 30 in a neonatal intensive care unit. J Pediatr 2005; 146: 523-7.

5. Wiedbrauk DL, Johnston SLG. Manuel of clinical virology, NewYork: Raven Press, 1993: 54.

6. Chaberny IE, Schnitzler P, Geiss HK, et al. An outbreak of epidemic keratoconjunctivitis in a pediatric unit due to adenovirus type 8. Infect Control Hosp Epidemiol 2003; 24: 514-9.

7. Birenbaum E, Linder N, Varsano N, et al. Adenovirus type 8 conjunctivitis outbreak in a neonatal intensive care unit. Arch Dis Child 1993; 68: 610-1.

8. Yagci R, Akçali A, Yagci S, et al. Molecular identification of adenoviral conjunctivitis in Turkey. Eur J Ophthalmol 2010; 20: 669-74.

9. Piedra PA, Kasel JA, Norton $\mathrm{HJ}$, et al. Description of an adenovirus type 8 outbreak in hospitalized neonates born prematurely. Pediatr Infect Dis J 1992; 11: 460-5.

10. Bordigoni P, Carret AS, Venard V, et al. Treatment of adenovirus infections in patients undergoing allogeneic hematopoietic stem cell transplantation. Clin Infect Dis 2001; 32: 1290-7.

11. Asencio-Durán M, Romero-Martín R, García-Martínez JR, et al. Nosocomial outbreak of epidemic keratoconjunctivitis in a neonatal intensive care unit. Arch Soc Esp Oftalmol 2007; 82: 73-9. 